\title{
Substituent effect of camphor sulfonamide ligand on the asymmetric addition of diethylzinc to aldehyde
}

\author{
Ai-Ling Hui, Jin-Tang Zhang, and Zhi-Yong Wang* \\ Hefei National Laboratory for Physical Science at Microscale and Department of Chemistry, \\ University of Science and Technology of China, Hefei Anhui, 230026, China \\ E-mail: zwang3@ustc.edu.cn
}

\begin{abstract}
A variety of camphor sulfonamide ligands were synthesized and employed in the addition of diethylzinc to aldehydes. The influences of substitution patterns, electronic property, reaction substrates, reaction solvents and temperature were studied. After optimization, the best reaction condition was determined and applied to this addition reaction, giving the corresponding products in high yields with up to $83 \%$ ee.
\end{abstract}

Keywords: Camphor sulfonamide, diethylzinc, aldehyde, substitution, enantioselective

\section{Introduction}

The addition of dialkylzinc to aldehydes or ketones is one of the most widely studied carboncarbon bond-forming reactions. The reacion can be carried out in an enantioselective fashion to provide enantio-enriched chiral alcohols. A multitude of chiral ligands have been used alone or in the presence of Lewis acids for this purpose. ${ }^{1}$ For example, amino alcohols, ${ }^{2-5}$ hydroxypyridine,${ }^{6}$ diol, ${ }^{7}$ hydroxy carboxylic acids, ${ }^{8} \alpha$-amino amide, ${ }^{9} \alpha$-hydroxy amides ${ }^{10}$ were employed in this asymmetric addition to aldehydes widely. Recently, a series of imino alcohols ${ }^{11}$ and hydroxysulfonamides ${ }^{12-15}$ were employed to catalyze this addition reaction and to control the stereoselectivity of this reaction. Moreover, by the optimization of ligands, the enantioselective addition of ketone with dialkylzinc was realized. ${ }^{16}$ However, to the best of our knowledge, no report has emerged about the electronic effect of the ligands on the enantioselectivity of this reaction. We designed and synthesized a variety of the hydroxysulfonamide ligands on the basis of alteration of the substitution patterns and the electronic effect, optimizing the reaction conditions and enhancing the reaction stereoselectivity. 


\section{Results and Discussion}

Based on the previous study about the addition reaction, first of all, the addition of diethylzinc to benzaldehyde catalyzed by the ligand in Figure 1 was chosen as research target since this ligand was efficient to induce the asymmetric addition of diethylzinc to benzaldehyde. ${ }^{12 \mathrm{e}}$ By altering the substituents and the corresponding substitution patterns on the phenyl ring we attempted to find the effect on the enantioselective addition of diethylzinc to aldehydes. Therefore a series of ligands with various substituents on the phenyl ring were synthesized. The reaction was carried out in toluene at $30^{\circ} \mathrm{C}$ in the presence of 1.3 equiv. $\mathrm{Ti}\left(\mathrm{O}^{\mathrm{i}} \mathrm{Pr}\right)_{4}$ (Scheme 1). The results were summarized in Table 1.

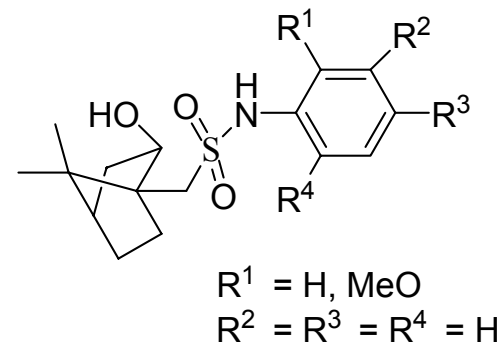

Figure 1. The efficient hydroxysulfonamide ligand for the asymmetric addition of diethylzinc to aldehyde.

$$
\underset{1 \text { equiv. }}{\mathrm{PhCHO}}+\underset{\mathrm{Et}_{2} \mathrm{Zn}}{1.8 \text { equiv. }} \underset{\mathrm{Li}^{*}(0.2 \text { equiv. }) / \text { toluene } \mathrm{O}_{4}(1.3 \text { equiv. })}{\longrightarrow}
$$

Scheme 1. Asymmetric addition of diethylzinc to aldehyde.

From Table 1 it was found that the substitution patterns and the electronic effect of substituents on the phenyl ring of camphor sulfonamide have different influences on the reaction yield and enantioselectivity of this addition. Generally, electron-withdrawing groups disfavored this reaction. In particular, the ortho-substituted or meta-substituted electron-withdrawing group in the phenyl ring of camphor sulfonamide resulted in the decrease in either the reaction yield or the corresponding ee value (entries 3, 8 and 9, Table 1), even the failure of the reaction (entry 2, Table 1). When the electron-withdrawing group was in the para-position of the phenyl ring, the reaction rate was decreased and the reactants were hard to use out. For example, the reactions in entries 10-12 could not be finished after the reaction were performed for more than $4 \mathrm{~h}$. In contrast, the electron-donating groups favored these reactions. For instance, when methyl, ethyl and phenyl groups were in the para-position of the phenyl ring, the reactions can be finished in 1 $\mathrm{h}$, giving the corresponding product with high yields and more than $70 \%$ ee (entries 14-16, Table 1). Nevertheless, when these electron-donating substitution on the ortho-position of the phenyl 
ring in camphor sulfonamide, either the reaction rate and yield or the ee value was reduced slightly due to steric hindrance (entries 4-6, Table 1). When the substituent was on the metaposition of the phenyl ring, the corresponding influence was dependent on the electronic property of the substituent. For example, fluo-substitution on the meta-position of the phenyl ring reduced the reaction yield and the corresponding ee slightly while nitro-substitution had a great negative influence on the reaction yield and the ee value (entries 7-9, Table 1). It was noted that nitrosubstitution has a special influence on the reaction and the influence was varied with the substitution patterns. The nitro-substitution in ortho-position resulted in the failure of the reaction. As for the nitro group in the meta-position of the phenyl ring, the addition reaction gave a slightly decreased enantiomeric excess $(64 \%$ ee) compared to that in the para-position of phenyl ring (entry 8 vs enry 13, Table 1). However, the reaction rate was very slow in this case, affording the corresponding product with only 46\% yield in 12 hours. The reason for this phenomenon perhaps stemmed from the participation of the nitro group into the reaction transition state. ${ }^{16}$ When nitro group was on the ortho-position of the phenyl ring, the oxygen atom of nitro group perhaps connected to metal titanium in this intermediate, resulting in that oxygen atom of reactant aldehyde could not coordinate with this titanium. Therefore no reaction was observed (entry 2, Table 1). When in the meta-position, the oxygen atom had a steric hindrance to the oxygen of the reactant aldehyde, resulting in the reduction in both reaction yield and the rate as well as in ee value (entries 8 and 9, Table 1). When in the para position, the size block of the nitro group was not dominant and the electronic effect of nitro group had an influence on this reaction, resulting in slightly lower yield and ee value. After this optimization, it was found that the ligand in entry 16 was the best ligand among these camphor sulfonamide derivatives.

On the basis of this selected ligand, next, the reaction solvent was optimized in detail. The experimental results were listed in Table 2. 
Table 1. The effect of different ligands on the reaction

\begin{tabular}{|c|c|c|c|}
\hline Entry & $\mathrm{R}$ & Yield $(\%)^{\mathrm{a}} /$ Time $(\mathrm{h})$ & ee $(\%)^{\mathrm{b}}$ (config. $)$ \\
\hline 1 & $\mathrm{R}^{2}=\mathrm{R}^{3}=\mathrm{R}^{4}=\mathrm{H}, \mathrm{R}^{1}=\mathrm{H}$ & $93 / 2$ & $70(\mathrm{~S})$ \\
\hline 2 & $\mathrm{R}^{2}=\mathrm{R}^{3}=\mathrm{R}^{4}=\mathrm{H}, \mathrm{R}^{1}=\mathrm{NO}_{2}$ & N. R. & \\
\hline 3 & $\mathrm{R}^{2}=\mathrm{R}^{3}=\mathrm{R}^{4}=\mathrm{H}, \mathrm{R}^{1}=\mathrm{Cl}$ & $52 / 4$ & $60(\mathrm{~S})$ \\
\hline $4^{\mathrm{c}}$ & $\mathrm{R}^{2}=\mathrm{R}^{3}=\mathrm{R}^{4}=\mathrm{H}, \mathrm{R}^{1}=\mathrm{OMe}$ & $>98$ & 66 \\
\hline 5 & $\mathrm{R}^{2}=\mathrm{R}^{3}=\mathrm{R}^{4}=\mathrm{H}, \mathrm{R}^{1}=\mathrm{Me}$ & $88 / 4$ & $48(\mathrm{~S})$ \\
\hline 6 & $\mathrm{R}^{3}=\mathrm{R}^{4}=\mathrm{H}, \mathrm{R}^{1}, \mathrm{R}^{2}=\mathrm{Ph}$ & $80 / 8$ & $54(\mathrm{~S})$ \\
\hline 7 & $\mathrm{R}^{1}=\mathrm{R}^{3}=\mathrm{R}^{4}=\mathrm{H}, \mathrm{R}^{2}=\mathrm{F}$ & $90 / 1$ & $68(\mathrm{~S})$ \\
\hline 8 & $\mathrm{R}^{1}=\mathrm{R}^{3}=\mathrm{R}^{4}=\mathrm{H}, \mathrm{R}^{2}=\mathrm{NO}_{2}$ & $46 / 12$ & $64(\mathrm{~S})$ \\
\hline 9 & $\mathrm{R}^{1}=\mathrm{R}^{3}=\mathrm{H}, \mathrm{R}^{2}=\mathrm{NO}_{2}, \mathrm{R}^{4}=\mathrm{Me}$ & $40 / 12$ & $37(\mathrm{~S})$ \\
\hline 10 & $\mathrm{R}^{1}=\mathrm{R}^{2}=\mathrm{R}^{4}=\mathrm{H}, \mathrm{R}^{3}=\mathrm{Cl}$ & $90 / 4$ & $70(\mathrm{~S})$ \\
\hline 11 & $\mathrm{R}^{1}=\mathrm{R}^{2}=\mathrm{R}^{4}=\mathrm{H}, \mathrm{R}^{3}=\mathrm{Br}$ & $88 / 4$ & $68(\mathrm{~S})$ \\
\hline 12 & $\mathrm{R}^{1}=\mathrm{R}^{2}=\mathrm{R}^{4}=\mathrm{H}, \mathrm{R}^{3}=\mathrm{I}$ & $85 / 4$ & $70(S)$ \\
\hline 13 & $\mathrm{R}^{1}=\mathrm{R}^{2}=\mathrm{R}^{4}=\mathrm{H}, \mathrm{R}^{3}=\mathrm{NO}_{2}$ & $93 / 1$ & $66(\mathrm{~S})$ \\
\hline 14 & $\mathrm{R}^{1}=\mathrm{R}^{2}=\mathrm{R}^{4}=\mathrm{H}, \mathrm{R}^{3}=\mathrm{Me}$ & $95 / 1$ & $71(\mathrm{~S})$ \\
\hline 15 & $\mathrm{R}^{1}=\mathrm{R}^{2}=\mathrm{R}^{4}=\mathrm{H}, \mathrm{R}^{3}=\mathrm{Et}$ & $96 / 1$ & $71(\mathrm{~S})$ \\
\hline 16 & $\mathrm{R}^{1}=\mathrm{R}^{2}=\mathrm{R}^{4}=\mathrm{H}, \mathrm{R}^{3}=\mathrm{Ph}$ & $95 / 1$ & $72(\mathrm{~S})$ \\
\hline
\end{tabular}

a isolated yield.

${ }^{\mathrm{b}}$ ee was determined by chiral HPLC.

${ }^{\mathrm{c}}$ The data were reported in Reference $12 \mathrm{e}$ in $20^{\circ} \mathrm{C}$.

Table 2. Solvent effect on this reaction

\begin{tabular}{cccc}
\hline Entry & Solvent & Yield (\%)/ Time (h) & ee (\%) (config.) \\
\hline 1 & Toluene & $95 / 1$ & $72(\mathrm{~S})$ \\
2 & Benzene & $75 / 12$ & $70(\mathrm{~S})$ \\
3 & Xylene & $92 / 1$ & $71(\mathrm{~S})$ \\
4 & Chlorobenzene & $94 / 1$ & $68(\mathrm{~S})$ \\
5 & Pyridine & N. R. & \\
6 & $\mathrm{CH}_{2} \mathrm{Cl}_{2}$ & $83 / 2$ & $58(\mathrm{~S})$ \\
7 & $\mathrm{n}-\mathrm{Hexane}_{8}$ & $85 / 2$ & $65(\mathrm{~S})$ \\
8 & $\mathrm{THF}$ & $83 / 2$ & $64(\mathrm{~S})$ \\
9 & $\mathrm{Et} 2 \mathrm{O}$ & $92 / 2$ & $68(\mathrm{~S})$ \\
10 & $\mathrm{MeCN}$ & $70 / 7$ & $50(\mathrm{~S})$ \\
11 & $\mathrm{DMF}$ & $\mathrm{N} . \mathrm{R}$. & \\
12 & $\mathrm{EtOH}$ & N. R. & \\
\hline
\end{tabular}


As shown in Table 2, the reaction was carried out in benzene, toluene and xylene, affording the corresponding products with good ee values (entries 1-3, Table 2). In comparison with benzene, toluene or xylene gave rise to the product with good yields and the corresponding reaction can be finished faster than that in benzene. Secondly, diethyl ether and chlorobenzene were also good solvents for this addition, giving the corresponding product with good yields but with slightly lower ee values (entries 4 and 9, Table 2). Dichloromethane, hexane, or THF can also be employed as solvents for this reaction (entries 6-8, Table 2). Nevertheless, either the enantioselectivities or the reaction yields in these solvents were lower than that in toluene (entries 6-8 vs entry 1, Table 2). When the reaction was carried out in $\mathrm{CH}_{3} \mathrm{CN}$, the ee value was reduced to $50 \%$ while the reaction yield decreased to $70 \%$ (entry 10 , Table 2 ). The reaction system was slurry and no desired product was obtained when we performed the reaction in pyridine, DMF or EtOH (entries 5, 11 and 12, Table 2). Perhaps the diethylzinc was destroyed in these solvents. As a result of this screening, toluene should be the best solvent among these organic solvents.

Subsequently, the effect of the amount of ligands and Lewis acid $\operatorname{Ti}\left(\mathrm{O}^{\mathrm{i}} \mathrm{Pr}\right)_{4}$ was also studied. As indicated in Table 3, both the yield and the enantiomeric excess were enhanced with the increase of the amount of ligand from 5\% equiv. to $20 \%$ equiv. (entries 1-4, Table 3 ). However, when the amount of ligand was increased to $50 \%$ equiv., either the reaction yield or the enantiomeric excess was decreased slightly (entry 5, Table 3 ). The variation of the amount of $\mathrm{Ti}\left(\mathrm{O}^{\mathrm{i} P r}\right)_{4}$ had a great influence on both the reaction yield and the ee value. When the amount of $\mathrm{Ti}\left(\mathrm{O}^{\mathrm{i}} \mathrm{Pr}\right)_{4}$ was reduced from 1.3 equiv. to 0.4 equiv., the enantioselectivity was lost totally while the reaction yield was decreased from $95 \%$ to $43 \%$ and the reaction time was prolonged from $1 \mathrm{~h}$ to $24 \mathrm{~h}$ (entries 4 and 9, Table 3). Beyond 1.4 equiv. of $\mathrm{Ti}\left(\mathrm{O}^{\mathrm{i}} \mathrm{Pr}\right)_{4}$ reaction yield was reduced while ee value was enhanced slightly with the increase of the amount of $\mathrm{Ti}\left(\mathrm{O}^{\mathrm{i}} \mathrm{Pr}\right)_{4}$ (entries 14-16, Table 3). In particular, when the amount of $\mathrm{Ti}\left(\mathrm{O}^{\mathrm{i}} \mathrm{Pr}\right)_{4}$ increased to 4.0 equiv., either reaction yield or ee value was decreased markedly (entry 17, Table 3). Further study demonstrated that liberated isopropanol in situ didn't affect the reaction (entry 6 vs 7, Table 3). Additionally, $\mathrm{Ti}\left(\mathrm{O}^{\mathrm{i}} \mathrm{Pr}\right)_{4}$ can be added to the flask at once (entry 7 vs 8 , Table 3 ) and the complexation was performed at room temperature (entry 8 vs 4 , Table 3 ). This experimental procedure is simpler in comparing with that reported previously ${ }^{12 \mathrm{e}}$.

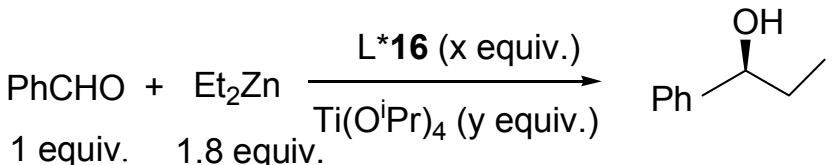


Table 3. Stoichiometry ${ }^{\mathrm{a}}$

\begin{tabular}{ccccc}
\hline Entry & $\mathrm{x}$ & $\mathrm{y}$ & ${\text { Yield }(\%)^{\mathrm{b}} / \text { Time}(\mathrm{h})}$ & ee $(\%)^{\mathrm{c}}($ config. $)$ \\
\hline 1 & 0.05 & 1.3 & $75 / 20$ & $51(\mathrm{~S})$ \\
2 & 0.1 & 1.3 & $81 / 20$ & $63(\mathrm{~S})$ \\
3 & 0.15 & 1.3 & $88 / 2$ & $67(\mathrm{~S})$ \\
4 & 0.2 & 1.3 & $95 / 1$ & $72(\mathrm{~S})$ \\
5 & 0.5 & 1.3 & $89 / 4$ & $64(\mathrm{~S})$ \\
$6^{\mathrm{d}}$ & 0.2 & 1.3 & $94 / 1$ & $70(\mathrm{~S})$ \\
$7^{\mathrm{e}}$ & 0.2 & 1.3 & $95 / 1$ & $71(\mathrm{~S})$ \\
$8^{\mathrm{f}}$ & 0.2 & 1.3 & $94 / 1$ & $70(\mathrm{~S})$ \\
9 & 0.2 & 0.4 & $43 / 24$ & 0 \\
10 & 0.2 & 0.6 & $82 / 4$ & $65(\mathrm{~S})$ \\
11 & 0.2 & 0.8 & $75 / 4$ & $65(\mathrm{~S})$ \\
12 & 0.2 & 1.0 & $78 / 1.5$ & $57(\mathrm{~S})$ \\
13 & 0.2 & 1.2 & $95 / 1.5$ & $71(\mathrm{~S})$ \\
14 & 0.2 & 1.4 & $90 / 4$ & $69(\mathrm{~S})$ \\
15 & 0.2 & 1.6 & $90 / 3$ & $71(\mathrm{~S})$ \\
16 & 0.2 & 2.0 & $84 / 7$ & $72(\mathrm{~S})$ \\
17 & 0.2 & 4.0 & $82 / 7$ & $62(\mathrm{~S})$ \\
\hline
\end{tabular}

${ }^{a}$ Unless other indicated, all reactions were carried out in this procedure. $\mathrm{L}^{*}(0.2$ equiv.) and $\mathrm{Ti}\left(\mathrm{O}^{\mathrm{i}} \mathrm{Pr}\right)_{4}(1.3$ equiv. $)$ were dissolved in the toluene $(2 \mathrm{ml})$ under $\mathrm{N}_{2}$ and the resulting mixture was stirred for $0.5 \mathrm{~h}$ at $30{ }^{\circ} \mathrm{C}$. $\mathrm{Et}_{2} \mathrm{Zn}$ (1.8 equiv.) was added and 5 min later benzaldehyde ( 1 equiv.) was added.

${ }^{\mathrm{b}}$ isolated yields.

${ }^{\mathrm{c}}$ The ee data were determined by chiral HPLC using OD-H column.

${ }^{d}$ Method A: $\mathrm{L}^{*}$ (0.2 equiv.) and $\mathrm{Ti}\left(\mathrm{O}^{\mathrm{i}} \mathrm{Pr}\right)_{4}$ ( 0.2 equiv.) were dissolved in toluene and the resulting mixture was heated to $65-70^{\circ} \mathrm{C}$ followed by azeotropic removal of isopropanol and toluene. 1.1 equiv $\mathrm{Ti}\left(\mathrm{O}^{\mathrm{i}} \mathrm{Pr}\right)_{4}$ and $2 \mathrm{ml}$ of toluene were added under $\mathrm{N}_{2}$. The next procedure is similar to the above mentioned.

${ }^{\mathrm{e}}$ Method B: Similar to Method A. The difference was that the produced isopropanol was not removed from the reaction system.

${ }^{\mathrm{f}}$ Method C: $\mathrm{L}^{*}\left(0.2\right.$ equiv.) and $\mathrm{Ti}\left(\mathrm{O}^{\mathrm{i}} \mathrm{Pr}\right)_{4}(1.3$ equiv.) were dissolved in the toluene $(2 \mathrm{ml})$ under $\mathrm{N}_{2}$ and the resulting mixture was heated to $65-70{ }^{\circ} \mathrm{C}$ during $30 \mathrm{~min}$. Subsequently, the reaction was performed in room temperature $30{ }^{\circ} \mathrm{C}$.

The temperature effect was also studied. The results were shown in Table 4 . The same ee were obtained when the reaction was performed in $20{ }^{\circ} \mathrm{C}$ or $30{ }^{\circ} \mathrm{C}$ (entries 1 and 2 in Table 4). Reducing the reaction temperature did not improve the corresponding enantioselectivity, the yield was reduced obviously (entries 3 and 4 vs entry 1 in Table 4). Using toluene as solvent, 
elevating reaction temperature induced a lower ee (entries 5 and 6 vs entry 1 in Table 4). However, when the reaction was carried out in xylene, elevating temperature resulted in the generation of undesired product and lower ee (entries 8 and 9 vs entry 7 in Table 4).

Table 4. Temperature effect

\begin{tabular}{cllcc}
\hline Entry & Solvent & $\mathrm{T}\left({ }^{\circ} \mathrm{C}\right)$ & Yield $(\%) /$ Time $(\mathrm{h})$ & ee $(\%)$ (config.) \\
\hline 1 & Toluene & 30 & $95 / 1$ & $72(\mathrm{~S})$ \\
2 & Toluene & 20 & $94 / 1$ & $72(\mathrm{~S})$ \\
3 & Toluene & 0 & $70 / 2$ & $66(\mathrm{~S})$ \\
4 & Toluene & -15 & $58 / 2$ & $70(\mathrm{~S})$ \\
5 & Toluene & 40 & $95 / 1$ & $70(\mathrm{~S})$ \\
6 & Toluene & 60 & $95 / 1$ & $63(\mathrm{~S})$ \\
7 & Xylene & 30 & $92 / 1$ & $71(\mathrm{~S})$ \\
8 & Xylene & 40 & $85 / 2$ & $67(\mathrm{~S})$ \\
9 & Xylene & 60 & $50 / 2$ & $57(\mathrm{~S})$ \\
\hline
\end{tabular}

Finally, the catalytic system was established. The ligand in entry 16 of Table 1 with $\mathrm{Ti}\left(\mathrm{O}^{\mathrm{i}} \mathrm{Pr}\right)_{4}$ in toluene at $30{ }^{\circ} \mathrm{C}$ was chosen to the best catalytic system for this asymmetric addition. The scope of the reaction substrates was extended under the condition. The results were summarized in Table 5.

From Table 5, it was found that substitution pattern and electronic property had important influences on this reaction. For benzaldehyde without substitution, the addition gave the corresponding products with high yields and good ee values. When electron-withdrawing group was introduced in the phenyl ring, the influence was varied with the substitution pattern. For example, the addition of 4-chloro benzaldehyde and 4-fluoro benzaldehyde were carried out smoothly with high yield and good ee (entries 4 and 5, Table 5). However, the reaction of 2chloro-benzaldehyde gave the desired product with a lower yield and longer reaction time, together with a marked reduction in ee value (entry 3 in Table 5). As for electron-donating substitution, the effect on the addition was also varied with the substituent and substitution pattern. For instance, 2-methoxy benzaldehyde and 4-methoxy benzaldehyde resulted in the reduction of ee (entries 6 and 9, Table 5). However, methyl-substitution on para-position of benzaldehyde also gave the desired product with moderate ee (entry 15 in Table 5). In contrast, the reaction of 2-methyl benzaldehyde gave the best enantioselectivity in all the cases $(83 \%$ ee, entry 14 in Table 5). Additionally, it was found that there was obvious decrease in enantioselectivity when substituent was introduced in the ortho-position of benzaldehyde (entries 3, 6-8 and 13, Table 5) while little variation in chemical yield and enantioselectivity was observed when para-substituted benzaldehyde was used as reaction substrate (entries 4, 5 and 15, Table 5). Methoxy-substituted benzaldehyde was an exception (entriy 9 in Table 5). It was noted that all substitutents containing oxygen atom had a great negative influence on this reaction, 
especially in ee value (entries 6-13 in Table 5), which could be attributed to the coordination of the oxygen atom of the substituent with diethylzinc. Therefore increasing the amount of $\mathrm{Et}_{2} \mathrm{Zn}$ should improve this reaction. For the reaction of 2-methoxy benzaldehyde, increasing the amount of diethylzinc effected a slight enhancement of ee while the corresponding reaction yield kept the same (entries 6, 7 and 8, Table 5). As for the reaction of 4-methoxy benzaldehyde, increasing the amount of diethylzinc can supplement the loss of the reaction yield and enhance the ee value (entries 9 and 10, Table 5). The similar effect was observed in the case of the reaction of piperonyl aldehyde (entries 11 and 12, Table 5). However, for the reaction of benzaldehyde, which contained the substituent without oxygen atom, increasing the amount of the diethylzinc resulted in longer reaction time and a slightly lower ee (entries 1 and 2, Table 5). Finally, 1naphthaldehyde was also a good substrate for this addition. The addition of diethylzinc to 1naphthaldehyde gave the corresponding product with good yield and $81 \%$ ee (entry 16 in Table $5)$.

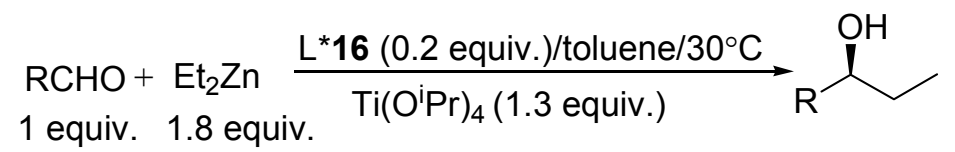

Table 5. Aldehyde effect

\begin{tabular}{|c|c|c|c|}
\hline Entry & Substrate & Yield (\%) ${ }^{\mathrm{a}} /$ Time (h) & ee $(\%)^{b}$ (config.) \\
\hline 1 & $\mathrm{Ph}$ & $95 / 1$ & $72(\mathrm{~S})$ \\
\hline $2^{\mathrm{c}}$ & $\mathrm{Ph}$ & $96 / 1.5$ & $68(\mathrm{~S})$ \\
\hline 3 & $2-\mathrm{ClC}_{6} \mathrm{H}_{4}$ & $85 / 10$ & $18(\mathrm{~S})$ \\
\hline 4 & $4-\mathrm{ClC}_{6} \mathrm{H}_{4}$ & $95 / 1$ & $69(\mathrm{~S})$ \\
\hline 5 & $4-\mathrm{FC}_{6} \mathrm{H}_{4}$ & $93 / 1$ & $75(S)$ \\
\hline 6 & $2-\mathrm{MeOC}_{6} \mathrm{H}_{4}$ & $96 / 1$ & $49(\mathrm{~S})$ \\
\hline $7^{c}$ & $2-\mathrm{MeOC}_{6} \mathrm{H}_{4}$ & $96 / 1$ & $52(\mathrm{~S})$ \\
\hline $8^{\mathrm{d}}$ & $2-\mathrm{MeOC}_{6} \mathrm{H}_{4}$ & $96 / 1$ & $56(\mathrm{~S})$ \\
\hline 9 & $4-\mathrm{MeOC}_{6} \mathrm{H}_{4}$ & $74 / 12$ & $23(\mathrm{~S})$ \\
\hline $10^{\mathrm{c}}$ & $4-\mathrm{MeOC}_{6} \mathrm{H}_{4}$ & $98 / 1.5$ & $35(\mathrm{~S})$ \\
\hline 11 & piperonyl & $76 / 12$ & 12 \\
\hline $12^{\mathrm{e}}$ & piperonyl & $96 / 1.5$ & 24 \\
\hline 13 & $2-\mathrm{OHC}_{6} \mathrm{H}_{4}$ & $90 / 2$ & 2 \\
\hline 14 & $2-\mathrm{MeC}_{6} \mathrm{H}_{4}$ & $88 / 4$ & $83(\mathrm{~S})$ \\
\hline 15 & $4-\mathrm{MeC}_{6} \mathrm{H}_{4}$ & $85 / 4$ & $66(\mathrm{~S})$ \\
\hline 16 & 1-naphthyl & $84 / 12$ & $81(\mathrm{~S})$ \\
\hline
\end{tabular}

${ }^{\mathrm{a}}$ Isolated yields after the column chromatography.

${ }^{\mathrm{b}}$ The ee data were determined by chiral HPLC and the configuration were assigned by the sign of the rotation.

${ }^{\mathrm{c}} 3$ equiv. $\mathrm{Et}_{2} \mathrm{Zn}$ was used.

${ }^{\mathrm{d}} 5$ equiv. $\mathrm{Et}_{2} \mathrm{Zn}$ was used.

${ }^{\mathrm{e}} 4$ equiv.Et ${ }_{2} \mathrm{Zn}$ was used. 


\section{Conclusions}

A variety of camphor sulfonamide derivatives have been synthesized and employed in the Ticatalyzed enantioselective addition of $\mathrm{Et}_{2} \mathrm{Zn}$ to aldehyde. Experimental results showed that the substitution patterns and the electronic property of the substituents had influence on the reaction yield and the corresponding ee value. By altering the substitution on the phenyl ring of the camphor sulfonamide, the most efficient ligand of the camphor sulfonamide derivatives was selected. Together with the optimization of reaction solvent, temperature and stoichiometry, the reaction condition and catalytic system were optimized. As a result, the reaction procedure was simplified and the reaction yield and the corresponding ee value were improved. The further improvement and the investigation for the reaction mechanism are in progress in our lab.

\section{Experimental Section}

General Procedures. Unless other indicated, all reactions using $\mathrm{Ti}\left(\mathrm{O}^{\mathrm{i}} \mathrm{Pr}\right)_{4}$ and diethylzinc were carried out in dry glassware under nitrogen. Hexane, tetrahydrofuran, ethyl ether, toluene, benzene were freshly distilled from sodium and benzophenone. Dichloromethane, acetonitrile were freshly distilled from $\mathrm{CaH}_{2}$. N, N-dimethyl formamide was distilled from $4 \AA$ MS under reduced pressure. Ethanol was distilled from magnesium and $\mathrm{CaH}_{2}$. Titanium tetraisopropoxide was freshly distilled under reduced pressure. Triehtylamine was distilled and stored in $4 \AA$ MS. Ethyl zinc solution was $1.1 \mathrm{M}$ in toluene and used directly. Reactions were monitored by thinlayer chromatography (TLC) analysis. ${ }^{1} \mathrm{H}$ NMR and ${ }^{13} \mathrm{C}$ NMR were recorded on a Bruker AC$300 \mathrm{FT}\left({ }^{1} \mathrm{H}: 300 \mathrm{MHz},{ }^{13} \mathrm{C}: 75.46 \mathrm{MHz}\right)$ using TMS as internal reference. The chemical shifts $(\delta)$ and coupling constants $(J)$ were expressed in ppm and Hz respectively. IR spectra were recorded on a Perkin-Elmer 2000 FTIR. High resolution mass spectra were obtained on GCT-TOF spectrometer. The optical rotations were measured on WZZ-2 polarimeter. Chiral HPLC was performed in an Agilent 1100 series instrument equipped with a diode array detector. Chiralcel OD-H column was purchased from Daicel chemical industries with $0.46 \mathrm{~cm} \Phi \times 25 \mathrm{~cm}$. Rention times for HPLC are given in minute.

Procedure for the preparation of ligand. Preparation of the Camphor sulfonyl chloride. D(+) camphor-10- sulfonyl acid $(9.3 \mathrm{~g}, 40 \mathrm{mmol})$ and $50 \mathrm{ml} \mathrm{SOCl} l_{2}$ were added to a flask. The resulting mixture was heated to $80-85{ }^{\circ} \mathrm{C}$ and was kept at temperature for 1 hour. Then the reaction was heated to $110-115{ }^{\circ} \mathrm{C}$ and stood at this temperature for another 2 hours. When the reaction was over, the excess $\mathrm{SOCl}_{2}$ was distilled and the crude mixture was purified by flash chromatography column using petroleum ether and ethyl acetate (4:1) as fluent solvent. The solvent was removed under reduced pressure and the desired camphor sulfonyl chloride was obtained as yellowy solid with $90-95 \%$ yield.

Preparation of the sulfonamide. To a solution of camphor sulfonyl chloride $(2.5 \mathrm{~g}, 10 \mathrm{mmol})$ in dry DMF $(10 \mathrm{ml})$ at $0^{\circ} \mathrm{C}$ was slowly added during $0.5 \mathrm{~h}$ another solution of corresponding 
benzylamine $(10 \mathrm{mmol})$, triethylamine $(12 \mathrm{mmol})$ in dry DMF $(10 \mathrm{ml})$. The resulting mixture was removed from ice bath and stirred at room temperature for another several hours. When the reaction was over, the mixture was poured into a $0.5 \mathrm{M} \mathrm{HCl}$ solution $(50 \mathrm{ml})$, and the obtained mixture was extracted with ethyl acetate $(3 \times 50 \mathrm{ml})$. The organic layer was washed with $\mathrm{HCl}$ solution and water, and dried over anhydrous $\mathrm{Na}_{2} \mathrm{SO}_{4}$. The solvents were removed under reduced pressure, obtaining the title compound. In some cases, the residue was purified by flash chromatography column and obtained the desired camphor sulfonamide with $85-95 \%$ yield.

Reduction of the sulfonamide. The above sulfonamide $(9 \mathrm{mmol})$ was dissolved in ethanol (30 $\mathrm{ml}$ ) or EtOH-THF at $0{ }^{\circ} \mathrm{C}$, and to this solution was added, with vigorous stirring, sodium borohydride $(30 \mathrm{mmol})$ many a time. The resulting mixture was stirred for $5 \mathrm{~min}$ to $1 \mathrm{~h}$ until TLC showed the material was consumed completely. The ethanol was removed under reduced pressure and the residue was dissolved in water $(25-30 \mathrm{ml})$ and extracted with ethyl acetate $(3 \times 40 \mathrm{ml})$. The organic layer was dried over anhydrous $\mathrm{Na}_{2} \mathrm{SO}_{4}$ and the solvent was removed yielding a residue, which was then purified by flash chromatography column to afford the expected exo-borneol derivative. In most cases, the endo-derivative can not be obtained.

$(1 S, 2 R, 4 S)-N$-Phenyl-2-hydroxy-7,7-dimethylbicyclo[2.2.1]hept-1-ylmethanesulfonamide (entry 1 in Table1). Yellowy oil, $[\alpha]_{\mathrm{D}}{ }^{27}=-32.3\left(c 0.5 \mathrm{CHCl}_{3}\right) ; \delta_{\mathrm{H}} 0.76(3 \mathrm{H}, \mathrm{s}), 1.01(3 \mathrm{H}, \mathrm{s})$, 1.10-1.16 (1 H, m), 1.51-1.82 (6 H, m), 2.65 (1 H, br), $2.98(1 \mathrm{H}, \mathrm{d}, J=13.7 \mathrm{~Hz}), 3.54(1 \mathrm{H}, \mathrm{d}, J$ $=13.7 \mathrm{~Hz}), 4.12-4.16(1 \mathrm{H}, \mathrm{m}), 6.83(1 \mathrm{H}, \mathrm{s}), 7.19-7.26(3 \mathrm{H}, \mathrm{m}), 7.33-7.39(2 \mathrm{H}, \mathrm{m}) \mathrm{ppm} ; \delta_{\mathrm{C}}$ $19.93,20.52,27.37,30.53,39.26,44.45,48.93,50.49,51.43,76.55,120.47,125.18,129.74$, 137.05 ppm; IR $v$ (film) 3537, 3264, 2960, 1496, 1329, 1146, $911 \mathrm{~cm}^{-1}$; HRMS Calcd $\mathrm{C}_{16} \mathrm{H}_{23} \mathrm{O}_{3} \mathrm{NS}: 309.1399$. Found: 309.1400 .

(1S,2R,4S)-N-(2-Nitrophenyl)-2-hydroxy-7,7-dimethylbicyclo[2.2.1]hept-1-ylmethane sulfonamide (entry 2 in Table 1). Orange oil, $[\alpha]_{\mathrm{D}}{ }^{27}=-25.3\left(c 0.5 \mathrm{CHCl}_{3}\right) ; \delta_{\mathrm{H}} 0.79(3 \mathrm{H}, \mathrm{s})$, 1.04 (3 H, s), 1.15-1.24 (1 H, m), 1.54-1.85 (6 H, m), 2.91 (1 H, br), 3.10 (1 H, d, J=13.8 Hz, ), 3.69 (1 H, d, $J=13.8 \mathrm{~Hz},), 4.13-4.17$ (1 H, m), 7.20-7.27 (1 H, m), 7.69- 7.71(1 H, m), 7.887.90(1 H, m), 8.26-8.30 (1 H, m), 9.86 (1 H, br) ppm; $\delta_{\mathrm{C}} 20.35,20.97,27.82,30.72,39.97$, $44.85,49.58,51.02,53.46,78.01,119.43,123.80,127.15,134.99,136.55,136.91 \mathrm{ppm}$; IR $v$ (film) $3560,3289,1612,1531,1488,1346,1145,916 \mathrm{~cm}^{-1}$; HRMS Calcd $\mathrm{C}_{16} \mathrm{H}_{22} \mathrm{~N}_{2} \mathrm{O}_{5} \mathrm{~S}: 354.1249$. Found: 354.1257.

(1S,2R,4S)- $N$-(2-Chlorophenyl)-2-hydroxy-7,7-dimethylbicyclo[2.2.1]hept-1-ylmethane sulfonamide (entry 3 in Table 1). White solid, m.p. $=117-119^{\circ} \mathrm{C} ;[\alpha]_{\mathrm{D}}{ }^{27}=-38.7\left(c 0.4 \mathrm{CHCl}_{3}\right)$; $\delta_{\mathrm{H}} 0.77(3 \mathrm{H}, \mathrm{s}), 1.01(3 \mathrm{H}, \mathrm{s}), 1.13-1.16(1 \mathrm{H}, \mathrm{m}), 1.50-1.56(1 \mathrm{H}, \mathrm{m}), 1.68-1.82(5 \mathrm{H}, \mathrm{m}), 2.98$ $(2 \mathrm{H}$, br and d overlap, $J=13.7 \mathrm{~Hz}), 3.53(1 \mathrm{H}, \mathrm{d}, J=13.7 \mathrm{~Hz}), 4.10-4.14(1 \mathrm{H}, \mathrm{m}), 6.85(1 \mathrm{H}$, br), 7.13-7.14 (1 H, m), 7.25-7.31 (1 H, m), 7.42-7.45 (1 H, m), 7.62-7.65 (1 H, m) ppm; $\delta_{\mathrm{C}}$ $19.91,20.57,27.41,30.43,39.26,44.45,48.97,50.56,52.33,76.40,121.89,124.78,126.07$, 128.38, 129.91, 133.79 ppm; IR v (KBr) 3488, 3146, 2954, 1479, 1328, 1144, $921 \mathrm{~cm}^{-1}$; HRMS Calcd $\mathrm{C}_{16} \mathrm{H}_{22} \mathrm{ClNO}_{3} \mathrm{~S}: 343.1009$. Found: 343.1001 .

(1S,2R,4S)-N-(2-Methylphenyl)-2-hydroxy-7,7-dimethylbicyclo[2.2.1]hept-1-ylmethane sulfonamide (entry 5 in Table 1). White solid, m.p. $=85-86^{\circ} \mathrm{C} ;[\alpha]_{\mathrm{D}}{ }^{27}=-41.4\left(c 0.5 \mathrm{CHCl}_{3}\right) ; \delta_{\mathrm{H}}$ 
0.79 (3 H, s), 1.03 (3 H, s), 1.10- 1.16 (1 H, m), 1.51-1.57 (1 H, m), 1.65-1.83 (5 H, m), 2.34 (3 H, s), 2.61(1 H, br), $3.01(1 \mathrm{H}, \mathrm{d}, J=13.5 \mathrm{~Hz}), 3.55$ (1 H, d, $J=13.5 \mathrm{~Hz}), 4.10-4.15(1 \mathrm{H}, \mathrm{m})$, 6.27 (1 H, br), 7.01-7.45 (3 H, m) ppm; $\delta_{\mathrm{C}} 18.26,19.99,20.63,27.42,30.50,39.20,44.49,48.89$, 50.61, 52.27, 76.51, 123.10, 126.14, 127.31, 131.00, 131.35, 134.94 ppm; IR $v$ (KBr) 3560, 3448, 3245, 2963, 1459, 1393, 1318, 1139, $899 \mathrm{~cm}^{-1}$; HRMS Calcd $\mathrm{C}_{17} \mathrm{H}_{25} \mathrm{NO}_{3} \mathrm{~S}$ : 323.1555. Found 323.1548 .

(1S,2R,4S)-N-(1-Naphthyl)-2-hydroxy-7,7-dimethylbicyclo[2.2.1]hept-1-ylmethane sulfonamide (entry 6 in Table 1). Pink solid, m.p. $=103-105^{\circ} \mathrm{C} ;[\alpha]_{\mathrm{D}}{ }^{27}=-24.5\left(c 0.5 \mathrm{CHCl}_{3}\right)$; $\delta_{\mathrm{H}} 0.73(3 \mathrm{H}, \mathrm{s}), 0.99(3 \mathrm{H}, \mathrm{s}), 1.07-1.13(1 \mathrm{H}, \mathrm{m}), 1.51-1.78(6 \mathrm{H}, \mathrm{m}), 2.83(1 \mathrm{H}, \mathrm{br}), 3.03(1 \mathrm{H}$, $\mathrm{d}, J=13.5 \mathrm{~Hz}), 3.60(1 \mathrm{H}, \mathrm{d}, J=13.5 \mathrm{~Hz}), 4.13-4.17(1 \mathrm{H}, \mathrm{m}), 7.00$ (1 H, br), 7.49-7.66 (4 H, m), $7.80(1 \mathrm{H}, \mathrm{d}, J=8.2 \mathrm{~Hz}), 7.92(1 \mathrm{H}, \mathrm{d}, J=8.2 \mathrm{~Hz}), 8.08(1 \mathrm{H}, \mathrm{d}, J=8.3 \mathrm{~Hz}) \mathrm{ppm} ; \delta_{\mathrm{C}} 19.92$, 20.55, 27.33, 30.50, 39.08, 44.39, 48.83, 50.57, 52.11, 76.63, 121.73, 122.06, 125.80, 126.57, 126.95, 127.26, 128.73, 131.76, 134.49 ppm; IR v (KBr) 3546, 3440, 3290, 2960, 1410, 1311, $1152 \mathrm{~cm}^{-1}$; HRMS Calcd $\mathrm{C}_{20} \mathrm{H}_{25} \mathrm{NO}_{3} \mathrm{~S}: 359.1555$. Found 359.1566.

(1S,2R,4S)-N-(3-Fluorophenyl)-2-hydroxy-7,7-dimethyl bicyclo[2.2.1]hept-1-ylmethane sulfonamide (entry 7 in Table 1). White solid, m.p. $=93-94^{\circ} \mathrm{C} ;[\alpha]_{\mathrm{D}}{ }^{27}=-37.8\left(c 0.4 \mathrm{CHCl}_{3}\right) ; \delta_{\mathrm{H}}$ 0.77 (3 H, s), 1.02 (3 H, s), 1.13- 1.16 (1 H, m), 1.51-1.60 (1 H, m), 1.69-1.82 (5 H, m), 3.00 (2 $\mathrm{H}$, d and br overlap, $J=13.7 \mathrm{~Hz}), 3.55(1 \mathrm{H}, \mathrm{d}, J=13.7 \mathrm{~Hz}), 4.13-4.17(1 \mathrm{H}, \mathrm{m}), 6.87-7.03(3 \mathrm{H}$, m), $7.16\left(1 \mathrm{H}\right.$, br), 7.28-7.32 (1 H, m) ppm; $\delta_{\mathrm{C}} 19.98,20.57,27.40,30.58,39.37,44.46,49.07$, 50.54, 51.79, 76.61, 107.18, 107.52, 111.78, 112.06, 115.35, 115.39, 131.04, 131.16, 138.60, 138.74, 161.75, 165.02 ppm; IR v (KBr) 3556, 3265, 2956, 1500, 1134, $976 \mathrm{~cm}^{-1}$; HRMS Calcd $\mathrm{C}_{16} \mathrm{H}_{22} \mathrm{FNO}_{3} \mathrm{~S}: 327.1304$. Found 327.1300 .

(1S,2R,4S)-N-(3-Nitrophenyl)-2-hydroxy-7,7-dimethylbicyclo[2.2.1]hept-1-ylmethane sulfonamide (entry 8 in Table 1). Yellow solid, m.p. $=175-177^{\circ} \mathrm{C} ;[\alpha]_{\mathrm{D}}{ }^{27}=-26.8\left(c 0.5 \mathrm{CHCl}_{3}\right)$; $\delta_{\mathrm{H}} 0.79(3 \mathrm{H}, \mathrm{s}), 0.95(3 \mathrm{H}, \mathrm{s}), 1.04-1.19(1 \mathrm{H}, \mathrm{m}), 1.50-1.85(6 \mathrm{H}, \mathrm{m}), 2.60(1 \mathrm{H}, \mathrm{br}), 3.02(1 \mathrm{H}$ $\mathrm{d}, J=13.7 \mathrm{~Hz}), 3.63(1 \mathrm{H}, \mathrm{d}, J=13.7 \mathrm{~Hz}), 4.16-4.20(1 \mathrm{H}, \mathrm{m}), 7.29(1 \mathrm{H}, \mathrm{br}), 7.52-7.60(2 \mathrm{H}$, m), 8.01-8.09 (2 H, m) ppm; $\delta_{\mathrm{C}} 20.05,20.65,27.46,30.68,39.68,44.59,49.21,50.68,52.72$, 76.45, 114.68, 119.74, 125.47, 130.83, 138.45 ppm; IR v (KBr) 3551, 3240, 2968, 1525, 1139 , $961 \mathrm{~cm}^{-1}$; HRMS Calcd $\mathrm{C}_{16} \mathrm{H}_{22} \mathrm{~N}_{2} \mathrm{O}_{5} \mathrm{~S}: 354.1249$. Found 354.1244.

$(1 S, 2 R, 4 S)-N$-(3-Nitro-6-methylphenyl)-2-hydroxy-7,7-di-methylbicyclo[2.2.1]hept-1ylmethanesulfonamide (entry 9 in Table 1). Orange solid, m.p. $=152-154^{\circ} \mathrm{C} ;[\alpha]_{\mathrm{D}}{ }^{27}=-23.7(c$ $\left.0.4 \mathrm{CHCl}_{3}\right) ; \delta_{\mathrm{H}} 0.82(3 \mathrm{H}, \mathrm{s}), 1.04(3 \mathrm{H}, \mathrm{s}), 1.11-1.17(1 \mathrm{H}, \mathrm{m}), 1.51-1.57(1 \mathrm{H}, \mathrm{m}), 1.75-1.83(5$ H, m), 2.44 (3 H, s), 2.70 (1 H, br), 3.06 (1 H, d, J=13.6 Hz), 3.67 (1 H, d, J = 13.6 Hz), 4.14$4.18(1 \mathrm{H}, \mathrm{m}), 6.73(1 \mathrm{H}, \mathrm{br}), 7.40(1 \mathrm{H}, \mathrm{d}, J=8.4 \mathrm{~Hz}), 7.98(1 \mathrm{H}, \mathrm{dd}, J=2.2,8.4 \mathrm{~Hz}), 8.35(1 \mathrm{H}$, $\mathrm{d}, J=2.2 \mathrm{~Hz}) \mathrm{ppm} ; \delta_{\mathrm{C}} 18.59,20.03,20.63,27.40,30.44,39.56,44.49,49.09,50.66,52.98$, 76.42, 116.51, 120.26, 131.89, 136.15, 137.36, 147.23 ppm; IR v (KBr) 3479, 3300, 2919, 1519, 1348, 1332, $1154 \mathrm{~cm}^{-1}$; HRMS Calcd for $\mathrm{C}_{17} \mathrm{H}_{24} \mathrm{~N}_{2} \mathrm{O}_{5} \mathrm{~S}: 368.1406$. Found 368.1415.

(1S,2R,4S)-N-(4-Chloro-phenyl)-2-hydroxy-7,7-dimethylbi-cyclo[2.2.1]hept-1-ylmethane

sulfonamide (entry 10 in Table 1). Colorless solid, m.p. $=87-89^{\circ} \mathrm{C} ;[\alpha]_{\mathrm{D}}{ }^{27}=-36.7(c 0.5$ $\left.\mathrm{CHCl}_{3}\right) ; \delta_{\mathrm{H}} 0.77(3 \mathrm{H}, \mathrm{s}), 1.04(3 \mathrm{H}, \mathrm{s}), 1.12-1.14(1 \mathrm{H}, \mathrm{m}), 1.53-1.81(6 \mathrm{H}, \mathrm{m}), 2.95(1 \mathrm{H}, \mathrm{d}, J=$ 
13.7 Hz), 3.06 (1 H, br), $3.51(1 \mathrm{H}, \mathrm{d}, J=13.7 \mathrm{~Hz}), 4.11-4.15(1 \mathrm{H}, \mathrm{m}), 6.82$ (1 H, br), 7.15-7.20 (2 H, m), 7.30-7.35 (2 H, m) ppm; $\delta_{\mathrm{C}} 19.96,20.55,27.36,30.55,39.36,44.45,19.01,50.51$, 51.58, 76.57, 121.94, 129.84, 130.77, 135.62 ppm; IR $v(\mathrm{KBr}) 3549,3262,2957,1492,1326$, 1147, $922 \mathrm{~cm}^{-1}$; HRMS Calcd $\mathrm{C}_{16} \mathrm{H}_{22}{ }^{35} \mathrm{ClNO}_{3} \mathrm{~S}$ : 343.1009 . Found 343.1003.

(1S,2R,4S)-N-(4-Bromophenyl)-2-hydroxy-7,7-dimethyl bicyclo[2.2.1]hept-1-ylmethane sulfonamide (entry 11 in Table 1). Colorless solid, m.p. $=88-90^{\circ} \mathrm{C} ;[\alpha]_{\mathrm{D}}{ }^{27}=-38.5(c 0.4$ $\left.\mathrm{CHCl}_{3}\right) ; \delta_{\mathrm{H}} 0.77(3 \mathrm{H}, \mathrm{s}), 1.02(3 \mathrm{H}, \mathrm{s}), 1.10-1.17(1 \mathrm{H}, \mathrm{m}), 1.52-1.83(6 \mathrm{H}, \mathrm{m}), 2.95(1 \mathrm{H}, \mathrm{d}, J=$ $13.7 \mathrm{~Hz}), 3.14$ (1 H, br), 3.52 (1 H, d, $J=13.7 \mathrm{~Hz}), 4.10-4.15$ (1 H, m), 7.04 (1 H, br), 7.10-7.15 $(2 \mathrm{H}, \mathrm{m}), 7.44-7.49$ (2 H, m) ppm; $\delta_{\mathrm{C}} 19.94,20.53,27.33,30.51,39.31,44.38,48.99,50.46$, 51.52, 76.54, 118.30, 122.04, 132.77, 136.13 ppm; IR v (KBr) 3445, 3263, 2956, 1489, 1328, 1138, $924 \mathrm{~cm}^{-1}$; HRMS Calcd for $\mathrm{C}_{16} \mathrm{H}_{22}{ }^{79} \mathrm{BrNO}_{3} \mathrm{~S}$ : 387.0504 . Found 387.0511.

(1S,2R,4S)-N-(4-Iodophenyl)-2-hydroxy-7,7-dimethylbicyclo[2.2.1]hept-1-ylmethane sulfonamide (entry 12 in Table 1). Brown solid, m.p. $=107-109^{\circ} \mathrm{C} ;[\alpha]_{\mathrm{D}}{ }^{27}=-33.9(c 0.4$ $\left.\mathrm{CHCl}_{3}\right) ; \delta_{\mathrm{H}} 0.77(3 \mathrm{H}, \mathrm{s}), 1.02(3 \mathrm{H}, \mathrm{s}), 1.07-1.16(1 \mathrm{H}, \mathrm{m}), 1.49-1.83(6 \mathrm{H}, \mathrm{m}), 2.95(2 \mathrm{H}, \mathrm{d}$ and br overlap, $J=13.7 \mathrm{~Hz}), J=13.7 \mathrm{~Hz}), 3.52(1 \mathrm{H}, \mathrm{d}, J=13.7 \mathrm{~Hz}), 4.11-4.15(1 \mathrm{H}, \mathrm{m}), 6.86(1 \mathrm{H}$, br), 6.97- $7.01(2 \mathrm{H}, \mathrm{m}), 7.64-7.68(2 \mathrm{H}, \mathrm{m}) \mathrm{ppm}$; $\delta_{\mathrm{C}} 19.98,20.58,27.39,30.57,39.38,44.46$, 49.04, 50.53, 51.72, 76.57, 88.94, 122.17, 136.89, 138.75 ppm; IR v (KBr) 3452, 3160, 2919, 1486, 1329, 1138, 922 $\mathrm{cm}^{-1}$; HRMS Calcd $\mathrm{C}_{16} \mathrm{H}_{22}{ }^{127} \mathrm{INO}_{3} \mathrm{~S}: 435.0365$. Found 435.0358.

(1S,2R,4S)-N-(4-Nitrophenyl)-2-hydroxy-7,7-dimethylbicyclo[2.2.1]hept-1-ylmethane sulfonamide (entry 13 in Table 1). Orange solid, m.p. $=158-159^{\circ} \mathrm{C} ;[\alpha]_{\mathrm{D}}{ }^{27}=-52.4(c 0.3$ $\left.\mathrm{CHCl}_{3}\right) ; \delta_{\mathrm{H}} 0.79(3 \mathrm{H}, \mathrm{s}), 1.04(3 \mathrm{H}, \mathrm{s}), 1.16-1.19(1 \mathrm{H}, \mathrm{m}), 1.54-1.57(1 \mathrm{H}, \mathrm{m}), 1.71-1.85(5 \mathrm{H}$, m), 2.83 (1 H, br), $3.07(1 \mathrm{H}, \mathrm{d}, J=13.8 \mathrm{~Hz}), 3.66(1 \mathrm{H}, \mathrm{d}, J=13.8 \mathrm{~Hz}), 4.15-4.19(1 \mathrm{H}, \mathrm{m})$, 7.31-7.35 (2 H, m), $7.64(1 \mathrm{H}, \mathrm{d}, J=7.0 \mathrm{~Hz}), 8.23-8.27(2 \mathrm{H}, \mathrm{m}) \mathrm{ppm} ; \delta_{\mathrm{C}} 19.96,20.53,27.37$, $30.56,39.63$, 44.47, 49.20, 50.63, 52.72, 76.56, 118.04, 125.82, 143.42, 143.88 ppm; IR v (KBr) 3437, 3084, 2956, 1596, 1524, 1344, 1138, 941 $\mathrm{cm}^{-1}$; HRMS Calcd $\mathrm{C}_{16} \mathrm{H}_{22} \mathrm{~N}_{2} \mathrm{O}_{5} \mathrm{~S}: 354.1249$. Found 354.1248.

$(1 S, 2 R, 4 S)-N$-(4-Methylphenyl)-2-hydroxy-7,7-dimethylbicyclo[2.2.1]hept-1-ylmethane sulfonamide (entry 14 in Table 1). Colorless solid, m.p. $=99-100^{\circ} \mathrm{C} ;[\alpha]_{\mathrm{D}}{ }^{27}=-46.2(c 0.3$ $\left.\mathrm{CHCl}_{3}\right) ; \delta_{\mathrm{H}} 0.76(3 \mathrm{H}, \mathrm{s}), 1.01(3 \mathrm{H}, \mathrm{s}), 1.06-1.12(1 \mathrm{H}, \mathrm{m}), 1.50-1.80(6 \mathrm{H}, \mathrm{m}), 2.33(3 \mathrm{H}, \mathrm{s})$, 2.84 (1 H, br), 2.94 (1 H, d, $J=13.7 \mathrm{~Hz}), 3.49$ (1 H, d, $J=13.7 \mathrm{~Hz}), 4.11-4.15(1 \mathrm{H}, \mathrm{m}), 6.70$ (1 H, br), 7.11-7.18 (4 H, m) ppm; $\delta_{\mathrm{C}} 19.96,20.58,20.94,27.40,30.56,39.21,44.45,48.94,50.48$, 51.14, 76.58, 121.29, 130.32, 134.25, 135.30 ppm; IR $v(\mathrm{KBr}) 3436,3257,2958,1510,1333$, $1140,925 \mathrm{~cm}^{-1}$; HRMS Calcd $\mathrm{C}_{17} \mathrm{H}_{25} \mathrm{NO}_{3} \mathrm{~S}$ : 323.1555 . Found 323.1558 .

(1S,2R,4S)-N-(4-Ethylphenyl)-2-hydroxy-7,7-dimethylbicyclo[2.2.1]hept-1-ylmethane sulfonamide (entry 15 in Table 1). Colorless solid, m.p. $=75-76^{\circ} \mathrm{C} ;[\alpha]_{\mathrm{D}}{ }^{27}=-64.7(c 0.3$ $\left.\mathrm{CHCl}_{3}\right) ; \delta_{\mathrm{H}} 0.76(3 \mathrm{H}, \mathrm{s}), 1.02(3 \mathrm{H}, \mathrm{s}), 1.10-1.16(1 \mathrm{H}, \mathrm{m}), 1.51-1.80(6 \mathrm{H}, \mathrm{m}), 1.23(3 \mathrm{H}, \mathrm{t}, J=$ $7.6 \mathrm{~Hz}), 2.64(3 \mathrm{H}$, br and q overlap, $J=7.6 \mathrm{~Hz}), 2.95(1 \mathrm{H}, \mathrm{d}, J=13.7 \mathrm{~Hz}), 3.50(1 \mathrm{H}, \mathrm{d}, J=$ $13.7 \mathrm{~Hz}), 4.11-4.16(1 \mathrm{H}, \mathrm{m}), 6.60$ (1 H, br), 7.13-7.20 (4 H, m) ppm; $\delta_{\mathrm{C}} 15.51,19.97,20.58$, $27.42,28.30,30.59,39.25,44.52,48.93,50.53,51.38,76.58,121.29,129.11,134.44,141.60$ 
ppm; IR v (KBr), 3552, 3450, 3287, 2958, 1469, 1144, $936 \mathrm{~cm}^{-1}$; HRMS Calcd $\mathrm{C}_{18} \mathrm{H}_{27} \mathrm{NO}_{3} \mathrm{~S}$ : 337.1712. Found 337.1720.

\section{(1S,2R,4S)- $N$-(4-Biphenyl)-2-hydroxy-7,7-dimethylbicyclo[2.2.1] hept-1-ylmethane} sulfonamide (entry 16 in Table 1). Brown solid, m.p. $=132-134^{\circ} \mathrm{C} ;[\alpha]_{\mathrm{D}}{ }^{27}=-35.4(c 0.4$ $\left.\mathrm{CHCl}_{3}\right) ; \delta_{\mathrm{H}} 0.78(3 \mathrm{H}, \mathrm{s}), 1.04(3 \mathrm{H}, \mathrm{s}), 1.11-1.17(1 \mathrm{H}, \mathrm{m}), 1.54-1.82(6 \mathrm{H}, \mathrm{m}), 3.03(1 \mathrm{H}, \mathrm{d}, J=$ $13.7 \mathrm{~Hz}), 3.15(1 \mathrm{H}, \mathrm{br}), 3.58(1 \mathrm{H}, \mathrm{d}, J=13.7 \mathrm{~Hz}), 4.15-4.19(1 \mathrm{H}, \mathrm{m}), 6.82(1 \mathrm{H}, \mathrm{br}), 7.28-7.60$ $(9 \mathrm{H}, \mathrm{m}) \mathrm{ppm} ; \delta_{\mathrm{C}} 20.00,20.60,27.43,30.62,39.32,44.49,49.02,50.58,51.67,76.62,120.84$, 126.94, 127.47, 128.41, 128.94, 136.00, 138.17, 140.12 ppm; IR v (KBr) 3474, 3137, 2957, 2920, 1487, 1142, $917 \mathrm{~cm}^{-1}$; HRMS Calcd $\mathrm{C}_{22} \mathrm{H}_{27} \mathrm{NO}_{3} \mathrm{~S}$ : 385.1712. Found 385.1713.

General procedure for the enantioselective addition of diethylzinc to aldehydes. Ligand $(0.1$ mmol, 0.2 equiv. $)$ and $\mathrm{Ti}\left(\mathrm{O}^{\mathrm{i}} \mathrm{Pr}\right)_{4}(185 \mathrm{mg}, 0.65 \mathrm{mmol}, 1.3$ equiv. $)$ were dissolved in toluene $(2 \mathrm{ml})$ or other solvents under nitrogen. The resulting mixture was stirred for 30 minutes at room temperature $\left(30{ }^{\circ} \mathrm{C}\right)$. Diethylzinc solution $(0.8 \mathrm{ml}, 0.9 \mathrm{mmol}, 1.1 \mathrm{M}$ in toluene, 1.8 equiv. $)$ was added to above flask and the color of solution became orange-green. After $5 \mathrm{~min}$, the corresponding aldehyde $(0.5 \mathrm{mmol}, 1$ equiv. $)$ was added at this temperature. The reaction was stirred for the appointed time in the Table 1,2, 3, 4 or 5 until it was quenched with diluted hydrochloric acid. The resulting mixture was filtered through silica gel, extracted with ethyl acetate $(3 \times 10 \mathrm{ml})$ and the organic layer dried over anhydrous $\mathrm{Na}_{2} \mathrm{SO}_{4}$. The solvent was removed under reduced pressure and the residue was purified by flash chromatography column to afford the expected sec-alcohol. The enantiomeric excess was determined by chiral HPLC.

1-Phenyl-1-propanol (entry 1 in Table 5). Colorless oil, $[\alpha]_{\mathrm{D}}{ }^{25}=-33.5\left(c 1.0, \mathrm{CHCl}_{3}\right) ; \delta_{\mathrm{H}} 0.91$ $(3 \mathrm{H}, \mathrm{t}, J=7.4 \mathrm{~Hz}), 1.70-1.87$ ( $3 \mathrm{H}, \mathrm{m}$ and s overlap), $4.59(1 \mathrm{H}, \mathrm{t}, J=6.4 \mathrm{~Hz}), 7.25-7.36(5 \mathrm{H}$, m) ppm; $\delta c 10.08,31.79,75.79,126.02,127.29,128.26,144.67$ ppm; IR $v$ (film) 3383, 3029, 2965, $2933 \mathrm{~cm}^{-1}$; HRMS Calcd $\mathrm{C}_{9} \mathrm{H}_{12} \mathrm{O}$ 136.0888. Found 136.0884; HPLC (chiralcel OD-H): nhexane $/ \mathrm{PrOH}=97: 3(\mathrm{~V} / \mathrm{V})$, flow rate $=0.5 \mathrm{ml} / \mathrm{min}, 25^{\circ} \mathrm{C}, 254 \mathrm{~nm}, \mathrm{RT}_{1}=20.2 \mathrm{~min}, \mathrm{RT}_{2}=22.9$ $\min$.

1-(2-Chlorophenyl)-1-propanol (entry 3 in Table 5). Colorless oil, $[\alpha]_{D}{ }^{25}=-10.5$ (c 2.0, $\left.\mathrm{CHCl}_{3}\right) ; \delta_{\mathrm{H}} 0.96(3 \mathrm{H}, \mathrm{t}, J=7.4 \mathrm{~Hz}), 1.65-1.83(2 \mathrm{H}, \mathrm{m}), 1.93(1 \mathrm{H}, \mathrm{s}), 5.03(1 \mathrm{H}, \mathrm{dd}, J=4.9,7.5$ $\mathrm{Hz}), 7.15-7.50$ (4 H, m) ppm; $\delta_{\mathrm{C}} 10.03,30.53,71.85,127.02,127.25,128.29,129.32,131.98$, $142.11 \mathrm{ppm}$; IR $v$ (film) 3383, 3068, 2967, $2934 \mathrm{~cm}^{-1}$; HRMS Calcd $\mathrm{C}_{9} \mathrm{H}_{11} \mathrm{ClO}: 170.0498$. Found 170.0492; HPLC (chiralcel OD-H): $\mathrm{n}$-hexane $/{ }^{\mathrm{i}} \mathrm{PrOH}=99: 1$, flow rate $=0.5 \mathrm{ml} / \mathrm{min}, 25^{\circ} \mathrm{C}, 220$ $\mathrm{nm}, \mathrm{RT}_{1}=30.5 \mathrm{~min}, \mathrm{RT}_{2}=31.5 \mathrm{~min}$.

1-(4-Chlorophenyl)-1-propanol (entry 4 in Table 5). Colorless oil, $[\alpha]_{\mathrm{D}}^{25}=-18.5(c$ 1.0, Benzene); $\delta_{\mathrm{H}} 0.90(3 \mathrm{H}, \mathrm{t}, J=7.4 \mathrm{~Hz}), 1.69-1.81(2 \mathrm{H}, \mathrm{m}), 1.84(1 \mathrm{H}, \mathrm{s}), 4.58(1 \mathrm{H}, \mathrm{t}, J=6.4 \mathrm{~Hz})$, 7.25-7.33 (4 H, m) ppm; $\delta c$ 9.96, 31.86, 75.14, 127.41, 128.43, 132.96, 143.09 ppm; IR $v$ (film) 3374, 2966, 2933, $2877 \mathrm{~cm}^{-1}$; HRMS Calcd $\mathrm{C}_{9} \mathrm{H}_{11} \mathrm{ClO}$ : 170.0498. Found 170.0493; HPLC (chiralcel OD-H): hexane $/{ }^{i} \mathrm{PrOH}=99: 1$, flow rate $=0.5 \mathrm{ml} / \mathrm{min}, 25^{\circ} \mathrm{C}, 260 \mathrm{~nm}, \mathrm{RT}_{1}=38.2 \mathrm{~min}$, $\mathrm{RT}_{2}=40.3$ min. 
1-(4-Fluorophenyl)propan-1-ol (entry 5 in Table 5). Colorless oil, $[\alpha]_{\mathrm{D}}{ }^{25}=-28.0$ (c 1.0, $\left.\mathrm{CHCl}_{3}\right) ; \delta_{\mathrm{H}} 0.90(3 \mathrm{H}, \mathrm{t}, J=7.4 \mathrm{~Hz}), 1.67-1.85(2 \mathrm{H}, \mathrm{m}), 1.94(1 \mathrm{H}, \mathrm{s}), 4.58(1 \mathrm{H}, \mathrm{t}, J=6.6 \mathrm{~Hz})$, 6.99-7.05 (2 H, m), 7.28-7.32 (2 H, m) ppm; $\delta_{\mathrm{C}} 10.01,31.93,75.26,114.96,115.24,127.61$, 127.72, 140.36, 140.40, 160.53, 163.77 ppm; IR $v$ (film) 3383, 2967, $1605 \mathrm{~cm}^{-1}$; HRMS calcd for $\mathrm{C}_{9} \mathrm{H}_{11} \mathrm{FO} 154.0794$ found 154.0796; HPLC (chiralcel OD-H column): hexane/ $\mathrm{PrOH}=$ 99.5:0.5; flow rate $=0.4 \mathrm{ml} / \mathrm{min}, 25^{\circ} \mathrm{C}, 270 \mathrm{~nm}, \mathrm{RT}_{1}=68.3 \mathrm{~min}, \mathrm{RT}_{2}=71.6 \mathrm{~min}$.

1-(2-Methoxyphenyl)-1-propanol (entry 8 in Table 5). Colorless oil, $[\alpha]_{\mathrm{D}}{ }^{25}=-35.6$ (c 1.0, Benzene); $\delta_{\mathrm{H}} 0.95$ (3 H, t, $\left.J=7.4 \mathrm{~Hz}\right), 1.77-1.86(2 \mathrm{H}, \mathrm{m}), 2.40$ (1 H,br), 3.84 (3H, s), 4.78 (1 H, $\mathrm{t}, J=6.6 \mathrm{~Hz}, 1 \mathrm{H}), 6.86-6.95(2 \mathrm{H}, \mathrm{m}), 7.23-7.30(2 \mathrm{H}, \mathrm{m}) \mathrm{ppm} ; \delta_{\mathrm{C}} 10.44,30.23,55.25,72.07$, 110.53, 120.71, 127.04, 128.15, 132.55, 156.61 ppm; IR v (film) 3406, $2964 \mathrm{~cm}^{-1}$; HRMS Calcd $\mathrm{C}_{10} \mathrm{H}_{14} \mathrm{O}_{2}$ : 166.0994. Found 166.0997; HPLC (chiralcel OD-H): $\mathrm{n}$-hexane/ ${ }^{\mathrm{i}} \mathrm{PrOH}=98: 2$, flow rate $=0.5 \mathrm{ml} / \mathrm{min}, 25^{\circ} \mathrm{C}, 270 \mathrm{~nm}, \mathrm{RT}_{1}=26.9 \mathrm{~min}, \mathrm{RT}_{2}=28.9 \mathrm{~min}$.

1-(4-Methoxyphenyl)-1-propanol (entry 10 in Table 5). Colorless oil, $[\alpha]_{\mathrm{D}}^{25}=-14.5$ (c 1.0, Benzene); $\delta_{\mathrm{H}} 0.89$ (3 H, t, $\left.J=7.4 \mathrm{~Hz}\right), 1.69-1.84$ ( $3 \mathrm{H}, \mathrm{m}$ and s overlap), 3.80 (3 H, s), 4.54 (1 H, t, $J=6.7 \mathrm{~Hz}), 6.86-6.89(2 \mathrm{H}, \mathrm{m}), 7.25-7.27(2 \mathrm{H}, \mathrm{m}) \mathrm{ppm} ; \delta \mathrm{c} 10.14,31.72,55.15,75.39$, 113.65, 127.20, 136.91, 158.82 ppm; IR $v$ (film) 3405, 2963, $2934 \mathrm{~cm}^{-1}$; HRMS Calcd for $\mathrm{C}_{10} \mathrm{H}_{14} \mathrm{O}_{2}$ 166.0994. Found 166.0996; HPLC (chiralcel OD-H): n-hexane/ $\mathrm{PrOH}=97: 3$, flow rate $=0.5 \mathrm{ml} / \mathrm{min}, 25^{\circ} \mathrm{C}, 270 \mathrm{~nm}, \mathrm{RT}_{1}=28.5 \mathrm{~min}, \mathrm{RT}_{2}=31.9 \mathrm{~min}$.

1-(Piperonyl)-1-propanol (entry 12 in Table 5). Yellowy oil, $[\alpha]_{\mathrm{D}}{ }^{25}=-8.3\left(c 1.5, \mathrm{CHCl}_{3}\right) ; \delta_{\mathrm{H}}$ $0.89(3 \mathrm{H}, \mathrm{t}, J=7.4 \mathrm{~Hz}), 1.66-1.84(3 \mathrm{H}, \mathrm{m}$ and s overlap), $4.50(1 \mathrm{H}, \mathrm{t}, J=6.7 \mathrm{~Hz}), 5.94(2 \mathrm{H}$, s), 6.77-6.85 (3 H, m) ppm; $\delta_{\mathrm{C}} 10.12,31.78,75.72,100.88,106.47,107.91,119.40,138.83$, 146.73, 147.65 ppm; IR $v$ (film) 3386, 2965, $2878 \mathrm{~cm}^{-1}$; HRMS Calcd $\mathrm{C}_{10} \mathrm{H}_{12} \mathrm{O}_{3}$ : 180.0786 Found 180.0782; HPLC (chiralcel OD-H): $n$-hexane $/{ }^{i} \mathrm{PrOH}=96: 4$, flow rate $=0.5 \mathrm{ml} / \mathrm{min}, 25^{\circ} \mathrm{C}$, $280 \mathrm{~nm}, \mathrm{RT}_{1}=29.2 \mathrm{~min}, \mathrm{RT}_{2}=31.2 \mathrm{~min}$.

1-(2-Hydroxyphenyl)-1-propanol (entry 13 in Table 5). yellowy oil, $\delta_{\mathrm{H}} 0.96(3 \mathrm{H}, \mathrm{t}, J=7.4$ $\mathrm{Hz}), 1.82-1.95(3 \mathrm{H}, \mathrm{m}), 4.75(1 \mathrm{H}, \mathrm{t}, J=6.7 \mathrm{~Hz}), 6.81-6.85(3 \mathrm{H}, \mathrm{m}), 7.14-7.25$ (1 H, m), 8.0 (1 $\mathrm{H}, \mathrm{s}) ; \delta_{\mathrm{C}} 10.23,30.30,77.50,117.14,119.81,127.44,127.48,128.89,155.52 \mathrm{ppm}$; IR $v$ (film) 3333, 2968, $2936 \mathrm{~cm}^{-1}$; HRMS Calcd $\mathrm{C}_{9} \mathrm{H}_{12} \mathrm{O}_{2}$ : 152.0837. Found 152.0844; HPLC (chiralcel OD-H): n-hexane $/{ }^{\mathrm{i}} \mathrm{PrOH}=99: 1$, flow rate $=0.5 \mathrm{ml} / \mathrm{min}, 25^{\circ} \mathrm{C}, 270 \mathrm{~nm}, \mathrm{RT}_{1}=21.6 \mathrm{~min}, \mathrm{RT}_{2}=$ $22.8 \mathrm{~min}$.

1-o-Tolylpropan-1-ol (entry 14 in Table 5). Colorless oil, $[\alpha]_{\mathrm{D}}{ }^{25}=-44.0(c 0.5$, Benzene); $v$ (film) $\delta_{\mathrm{H}} 0.98(3 \mathrm{H}, \mathrm{t}, J=7.4 \mathrm{~Hz}), 1.72-1.81(3 \mathrm{H}, \mathrm{m}$ and s overlap), $2.34(3 \mathrm{H}, \mathrm{s}), 4.87(1 \mathrm{H}, \mathrm{t}, J$ $=6.3 \mathrm{~Hz}), 7.12-7.26(3 \mathrm{H}, \mathrm{m}), 7.44-7.47(1 \mathrm{H}, \mathrm{m}) \mathrm{ppm} ; \delta_{\mathrm{C}} 10.28,19.00,30.86,71.84,125.33$, 126.12, 126.95, 130.22, 134.51, 142.82 ppm; IR $v$ (film) 3357, 2964, $1460 \mathrm{~cm}^{-1}$; HRMS calcd for $\mathrm{C}_{10} \mathrm{H}_{14} \mathrm{O}$ 150.1045, found 150.1040; HPLC (chiralcel OD-H column): hexane/ ${ }^{\mathrm{i}} \mathrm{PrOH}=98: 2$, flow rate $=0.3 \mathrm{ml} / \mathrm{min} ; 25^{\circ} \mathrm{C}, 254 \mathrm{~nm}, \mathrm{RT}_{1}=40.5 \mathrm{~min}, \mathrm{RT}_{2}=44.0 \mathrm{~min}$.

1-(4-Methylphenyl)-1-propanol (entry 15 in Table 5). Coloress oil, $[\alpha]_{\mathrm{D}}{ }^{25}=-28.0$ (c 1.0, Benzene); $\delta_{\mathrm{H}} 0.90$ (3 H, t, $\left.J=7.4 \mathrm{~Hz}\right), 1.70-1.84$ (3 H, m and s overlap), 2.34 (3 H, s), 4.55 (1 H, $\mathrm{t}, J=6.6 \mathrm{~Hz}), 7.13-7.25(4 \mathrm{H}, \mathrm{m}) \mathrm{ppm} ; \delta_{\mathrm{C}} 10.13,21.04,31.74,75.66$, 125.98, 128.94, 136.84, 141.75 ppm; IR v (film) 3381, 2966, 2933, $2875 \mathrm{~cm}^{-1}$; HRMS Calcd $\mathrm{C}_{10} \mathrm{H}_{14} \mathrm{O}: 150.1045$. Found 
150.1048; HPLC (chiralcel OD-H); $\mathrm{n}-$ hexane $/{ }^{\mathrm{i}} \mathrm{PrOH}=99.5: 0.5$, flow rate $=0.4 \mathrm{ml} / \mathrm{min}, 25^{\circ} \mathrm{C}$, $260 \mathrm{~nm}, \mathrm{RT}_{1}=67.1 \mathrm{~min}, \mathrm{RT}_{2}=70.1 \mathrm{~min}$.

1-(1-Hydroxypropyl)naphthalene (entry 16 in Table 5). Yellow oil, $[\alpha]_{\mathrm{D}}{ }^{25}=-53.0$ (c 0.5 , $\left.\mathrm{CHCl}_{3}\right) ; \delta_{\mathrm{H}} 1.03(3 \mathrm{H}, \mathrm{t}, J=7.1 \mathrm{~Hz}), 1.85(1 \mathrm{H}, \mathrm{s}), 1.88-2.07(2 \mathrm{H}, \mathrm{m}), 5.40(1 \mathrm{H}, \mathrm{dd}, J=5.1,7.4$ $\mathrm{Hz}), 7.47-8.10(7 \mathrm{H}, \mathrm{m}) \mathrm{ppm} ; \delta_{\mathrm{C}} 10.51,31.11,72.46,123.00,123.31,125.43,125.47,125.89$, 127.82, 128.90, 130.58, 133.85, 140.32 ppm; IR $v$ (film) 3384, 3052, 2966, $2929 \mathrm{~cm}^{-1}$; HRMS Calcd $\mathrm{C}_{13} \mathrm{H}_{14} \mathrm{O}$ : 186.1045. Found 186.1054; HPLC (chiralcel OD-H): n-hexane/ ${ }^{\mathrm{i}} \mathrm{PrOH}=91: 9$, flow rate $=0.5 \mathrm{ml} / \mathrm{min}, 25^{\circ} \mathrm{C}, 270 \mathrm{~nm}, \mathrm{RT}_{1}=16.3 \mathrm{~min}, \mathrm{RT}_{2}=27.8 \mathrm{~min}$.

\section{Acknowledgements}

The authors are grateful to National Natural Science Foundation of China (No.20472078 and 30572234) for financial support.

\section{References}

1. $\mathrm{Pu}, \mathrm{L} . ; \mathrm{Yu}, \mathrm{H}$. B. Chem. Rev. 2001, 101, 757.

2. (a) Kitamura, M.; Suga, S.; Kawai, K.; Noyori, R. J. Am. Chem. Soc. 1986, 108, 6071. (b) Noyori, R.; Suga, S.; Kawai, K.; Okada, S.; Kitamura, M.; Oguni, N.; Hayashi, M.; Kaneko, T.; Matsuda, Y. J. Organomet. Chem. 1990, 382, 19. (c) Noyori, R.; Kitamura, M. Angew. Chem., Int. Ed. 1991, 30, 49.

3. (a) Wu, X. Y.; Liu, X. Y.; Zhao, G. Tetrahedron: Asymmetry 2005, 16, 2299. (b) Park, J. K.; Lee, H. G.; Bolm, C.; Kim, B. M. Chem. Eur. J. 2005, 11, 945. (c) Cobb, A. J. A.; Marson, C. M. Tetrahedron 2005, 61, 1269. (d) Tseng, S. L.; Yang, T. K. Tetrahedron: Asymmetry 2004, 15, 3375. (e) Sibi, M. P.; Stanley, L. M. Tetraheron: Asymmetry 2004, 15, 3353. (f) Mao, J. C.; Wan, B. S.; Wang, R. L.; Wu, F.; Lu, S. W. J. Org. Chem. 2004, 69, 9123. (g) Da, C. S.; Han, Z. J.; Ni, M.; Yang, F.; Liu, D. X.; Zhou, Y. F.; Wang, R. Tetrahedron: Asymmetry 2003, 14, 659. (h) Wu, Y. J.; Yun, H. Y.; Wu, Y. S.; Ding, K. L.; Zhou, Y. Tetrahedron: Asymmetry 2000, 11, 3543. (i) Dosa, P. I.; Fu, G. C. J. Am. Chem. Soc. 1998, $120,445$.

4. (a) Ji, J. X.; Wu, J.; Au-Yeung, T. T. L.; Yip, C. W.; Haynes, R. K.; Chan, A. S. C. J. Org. Chem. 2005, 70, 1093. (b) Panda, M.; Phuan, P. W.; Kozlowski, M. C. J. Org. Chem. 2003, 68, 564. (c) Cimarelli, C.; Palmieri, G.; Volpini, E. Tetrahedron: Asymmetry 2002, 13, 2417. (d) Lu, J.; Xu, X.; Wang, S. Z.; Wang, C. D.; Hu, Y. F.; Hu, H. W. J. Chem. Soc., Perkin Trans. 1 2002, 2900.

5. (a) Scarpi, D.; Lo Galbo, F.; Occhiato, E. G.; Guarna, A. Tetrahedron: Asymmetry 2004, 15, 1319. (b) García Martínez, A.; Teso Vilar, E.; García Fraile, A.; de la Moya Cerero, S.; Lora Maroto, B. Tetrahedron: Asymmetry 2003, 14, 1959. (c) Trabocchi, A.; Menchi, G.; Rolla, 
M.; Machetti, F.; Bucelli, I.; Guarna, A. Tetrahedron 2003, 59, 5251. (d) Hanyu, N.; Aoki, T.; Mino, T.; Sakamoto, M.; Fujita, T. Tetrahedron: Asymmetry 2000, 11, 2971.

6. (a) Chen, Y. J.; Lin, R. X.; Chen, C. P. Tetrahedron: Asymmetry 2004, 15, 3561. (b) Huang, H. M.; Chen, H. L.; Hu, X. Q.; Bai, C. M.; Zheng, Z. Tetrahedron: Asymmetry 2003, 14, 297. (c) Zhong, Y. W.; Lei, X. S.; Lin, G. Q. Tetrahedron: Asymmetry 2002, 13, 2251. (d) Goanvic, D. L.; Holler, M.; Pale, P. Tetrahedron: Asymmetry 2002, 13, 119.

7. For TADDOLs as ligands, see: (a) Schmidt, B.; Seebach, D. Angew. Chem., Int. Ed. 1991, 30, 99. (b) Seebach, D.; Behrendt, L.; Felix, D. Angew. Chem., Int. Ed. 1991, 30, 1008. (c) Schmidt, B. Seebach, D. Angew. Chem., Int. Ed. 1991, 30, 1321. (d) von dem BusscheHünnefeld, J. L.; Seebach, D. Tetrahedron 1992, 48, 5719. (e) Seebach, D.; Plattner, D. A.; Beck, A. K.; Wang, Y. M.; Hunziker, D.; Petter, W. Helv. Chim. Acta 1992, 75, 2171. (f) Seebach, D.; Beck, A. K.; Schimdt, B.; Wang, Y. M. Tetrahedron 1994, 50, 4363. (g) Weber, B.; Seebach, D. Tetrahedron 1994, 50, 7473. (h) Ito, Y. N.; Ariza, X.; Beck, A. K.; Boháč, A.; Ganter, C.; Gawley, R. E.; Kühnle, F. N. M.; Tuleja, J.; Wang, Y. M.; Seebach, D. Helv. Chim. Acta 1994, 77, 2071. For BINOLs as ligand, see: (a) Zhang, F. Y.; Yip, C. W.; Cao, R.; Chan, A. S. C. Tetrahedron: Asymmetry 1997, 8, 585. (b) Mori, M.; Nakai, T. Tetrahedron Lett. 1997, 38, 6233.

8. (a) Bauer, T.; Gajewiak, J. Tetrahedron 2004, 60, 9163. (b) Bauer, T.; Tarasiuk, J. Tetrahedron Lett. 2002, 43, 687.

9. Burguete, M. I.; Collado, M.; Escorihuela, J.; Galindo, F.; García-Verdugo, E.; Luis, S. V.; Vicent, M. J. Tetrahedron Lett. 2003, 44, 6891.

10. Blay, G.; Fernóndez, I.; Hernóndez-Olmos, V.; Marco-Aleixandre, A.; Pedro, J. R. Tetrahedron: Asymmetry 2005, 16, 1953.

11. (a) Mino, T.; Oishi, K.; Yamashita, M. Synlett 1998, 965. (b) Fleischer, R.; Braun, M. Synlett 1998, 1441.

12. (a) Yus, M.; Ramón, D. J. Pure. Appl. Chem. 2005, 77, 2111. (b) Yus, M.; Ramón, D. J.; Prieto, O. Tetrahedron: Asymmetry 2003, 14, 1103. (c) Yus, M.; Ramón, D. J.; Prieto, O. Tetrahedron: Asymmetry 2002, 13, 1573. (d) Prieto, O.; Ramón, D. J.; Yus, M. Tetrahedron: Asymmetry 2000, 11, 1629. (e) Ramón, D. J.; Yus, M. Tetrahedron: Asymmetry 1997, 8, 2479.

13. Bauer, T.; Gajewiak, J. Tetrahedron 2003, 59, 10009.

14. (a) Guo, C.; Qiu, J.; Zhang, X. M.; Verdugo, D.; Larter, M. L.; Christie, R.; Kenney, P.; Walsh, P. J. Tetrahedron 1997, 53, 4145. (b) Qiu, J.; Guo, C.; Zhang, X. M. J. Org. Chem. 1997, 62, 2665. (c) Zhang, X. M.; Guo, C. Tetrahedron Lett. 1995, 36, 4947.

15. Ito, K.; Kimura, Y.; Okamura, H.; Katsuki, T. Synlett 1992, 573.

16. Ramón, D. J.; Yus, M. Tetrahedron 1998, 54, 5651. 